\title{
HUBUNGAN TINGKAT STRESS TERHADAP SIKLUS MENSTRUASI DI ASRAMA PUTRI AKPER ALMAARIF
}

\author{
RELATIONSHIP STRESS LEVEL AGAINST THE MENSTRUAL CYCLE IN THE RELIGION \\ OF AL MA'ARIF NURSING ACADEMY
}

\author{
Siska Delvia ${ }^{1}$, Muhammad Hasan Azhari ${ }^{2}$ \\ ${ }^{I}$ Program Studi Kebidanan, Sekolah Tinggi Ilmu Kesehatan Al-Ma'arif Baturaja, Jl Dr Mohammad Hatta No \\ 687-B Sukaraya, Baturaja, Sumatera Selatan, Indonesia 32112, Kab. Ogan Komering Ulu, Sumatera Selatan, \\ Indonesia \\ ${ }^{2}$ Akademi Keperawatan Kesdam II Sriwijaya, Jl Sultan Mahmud Badaruddin II No. 130132, Palembang, \\ Sumatera Selatan \\ email: siska.delvia26@gmail.com
}

\begin{abstract}
ABSTRAK
Kesehatan reproduksi menurut WHO (World Health Organization) batasan usia remaja adalah 12 - 24 tahun. Menurut survei kesehatan reproduksi Indonesi ( SKRRI) remaja adalah laki- laki dan perempuan yang berusia 15- 24 tahun 2019. Penelitian di Jepang, dari 221 responden dengan kondisi stres terdapat sebanyak 63\% pelajar mahasiswi mengalami menstruasi tidak teratur. Penelitian ini dilakukan untuk mengetahui hubungan stres dengan siklus menstruasi yang tidak teratur pada mahasiswi Akper Al-Maarif Baturaja. Penelitian dilakukan dengan menggunakan metode analitik dengan desain cross sectional. Populasi pada penelitian ini adalah mahasiswi Akper Al-Maarif, total sampel yang digunakan berjumlah 82 mahasisiswi yang berpartisipasi pada penelitian ini dan mengisi kuesioner secara lengkap. Waktu penelitian dilakukan pada bulan Mei 2016. Data diperoleh dari kuesioner yang dibagikan kepada responden. Teknik pengolahan data diolah dengan bantuan komputer (SPSS 16.0). Hasil penelitian menunjukkan 59,7\% responden dengan stres didapati 40,2\% responden mengalami siklus menstruasi yang tidak teratur, dan dari $63 \%$ yang tidak stres didapati $38 \%$ mengalami siklus mentruasi yang tidak teratur. Berdasarkan hasil uji chi square, dijumpai hubungan yang signifikan dengan siklus menstruasi yang tidak teratur dimana p value 0,005(<0,05).
\end{abstract}

Kata kunci: stres, siklus menstruasi yang tidak teratur

\begin{abstract}
According to the health of reproduction WHO (World Health Organization) definition adolescence is from 12 14 years old. According to health is reproduction is Indonesian ( SKRRI) adolescence is from 14-15 years old. Research in japan from 221 respondence in stress condition almost $61 \%$ of students is university get menstrual irregular. This research was conducted to determine the relationship of stress with an irregular menstrual cycle on the students Akper Al-Maarif Baturaja. The research was conducted using the analytical method with a cross-sectional design. The population in this study is the students of the Faculty of Akper Al-Maarif, and the total sample used was 82 students who participated in this study and answering a set and complete questionnaires. At the very least. The study was conducted from May to June 2016. Data obtained from questionnaires that have been distributed to respondents. The computer program SPSS 16.0 helps the processing of the data. The results showed that 59,7\% of respondents with stress were found and 40,2\% of the respondents experienced an irregular menstrual cycle. Other results showed that $63 \%$ who didn't stress had irregular menstrual cycles (38\% of them). Based on the results of the chi-square test, we found a significant relationship with the irregularity of the menstrual cycles in which the p-value is $0.003(<0.05)$.
\end{abstract}

Keyword: Stress, Irregular Menstrual Cycle 


\section{PENDAHULUAN}

Kesehatan merupakan suatu keadaan kesejahteraan fisik, mental dan sosial yang sempurna. Dalam perjalanan hidup, masa remaja adalah suatu periode transisi yang memiliki rentang dari masa kanak kanak yang bebas dari tanggung jawab sampai mencapai tanggung jawab masa remaja. Menurut WHO batasan usia remaja adalah 10 sampai 20 tahun ${ }^{1}$. Perubahan yang terjadi sangat pesat dalam dimensi fisik, mental dan sosial. Masa remaja adalah periode pencarian identitas diri, sehingga remaja sangat mudah terpengaruh oleh lingkungan. Umumnya proses pematangan fisik lebih cepat dari pematangan psikologisnya. Pada hal ini sering terjadi ketidakseimbangan yang menyebabkan remaja sangat sensitif dan rawan terhadap stres ${ }^{2}$.

Kesehatan reproduksi menurut WHO (World Health Organization) batasan usia remaja adalah 12- 24 tahun. Menurut survei kesehatan reproduksi Indonesi ( SKRRI) remaja adalah laki- laki dan perempuan yang berusia 15- 24 tahun ${ }^{3}$. Penelitian di Jepang, dari 221 responden dengan kondisi stres terdapat sebanyak $63 \%$ pelajar mahasiswi mengalami menstruasi tidak teratur ${ }^{4}$.

Penelitian yang dilakukan di beberapa universitas di Turkey didapatkan gangguan menstruasi berupa ketidakteraturan siklus menstruasi sebanyak $31,2 \%{ }^{5}$.

Pada penelitian lain didapatkan prevalensi gangguan siklus, amenorea primer sebanyak 5,3\% responden, amenorea sekunder sebanyak 18,4\% responden, oligomenorea sebanyak 50\% responden, polimenorea sebanyak 10,5\% responden, dan gangguan campuran (amenorea sekunder,oligomenorea dan polimenorea) sebanyak $15,8 \%$ responden ${ }^{6}$. Pada populasi di Amerika Serikat menunjukkan sebanyak 19\% wanita usia 18-55 tahun mengalami gangguan dengan menstruasinya, dan juga dari hasil penelitian di India, mayoritas dari wanita yang dilaporkan memiliki rata-rata sebanyak 37,9\% mengalami menstruasi tidak teratur ${ }^{7}$.

Di Indonesia perempuan berusia 20-24 tahun yang memiliki siklus menstruasi teratur sebanyak $76,7 \%$ responden dan yang tidak teratur sebanyak 14,4\% responden, sedangkan di Provinsi Sumatera Utara didapatkan sebanyak $68,3 \%$ responden dengan siklus yang teratur dan sebanyak $11,6 \%$ responden dengan siklus tidak teratur ${ }^{8}$.

Di Provisini Sumatra Barat Mahasiswi UNAND meneliti 22 dari 30 mahasiswi asrama sebanyak $73,33 \%$ mengalami tingkat stres sedang dalam 3 bulan terakhir karena berbagai faktor seperti kecemasan karena ujian semester yang semakin dekat, tugas perkuliahan yang menumpuk, permasalahan dengan teman. Masalah keuangan ataupun masalah homesick, 8 dari 30 mahasiswi sebanyak $26,67 \%$ diantranya mengalami tingkat stress ringan, sedangkan 16 dari 30 mahasiswi sebanyak 53,33\% mengalami siklus menstruasi normal 21-35 hari. Lama pendarahan dari 6 hari responden 9 dari 30 mahasiswi sebanyak $30 \%$ mengalami siklus panjang 35 hari, dan 5 dari 30 mahasiswi sebanyak $16,67 \%$ mengalami siklus pendek 21 hari, 18 dari 30 mahasiswi sebanyak $60 \%$ menyatakan adanya perubahan jika terjadi stressor seperti menstruasi yang terlambat selam 2 bulan ( 2 bulan tidak mengalami mens), siklus menstruasi yang lebih cepat, darah menstruasi yang lebih banyak, serta perut kram /desminore .

Di DINKES Kabupaten OKU Kecamatan Baturaja Kelurahan Sukaraya dengan responden berjumlah 37 remaja putri 3 bulan terakhir berobat ke puskesmas 
sukaraya dengan berbagai keluhan, dan 5 responden yang mengalami gangguan menstruasi. Kebanyakan wanita remaja yang mengalami gangguan menstruasi tidak berobat ke puskesmas melainkan menganggulangi dengan sendiri di rumahnya.

Salah satu contoh mahasiswa baru yang tinggal dilingkungan asrama di wajibakan mengikuti kegiatan asrama yang beraneka ragam seperti bergotong royong, mentoring agama dan banyak agenda lainya di samping kegiatan belajar. Selama tinggal diasrama, mahasiswa juga di wajibkan mematuhi tata tertib kehidupan asrama yang sudah di sepakati. Maka pola kegiatan sehari-harinya mempunyai perubahan ketika telah memasuki hari baru.

\section{METODE PENELITIAN}

Desain penelitian ini menggunakan metode survey analitik dengan pendekatan cros sectional, dimana data yang menyangkut variabel independen ( Tingkat Stress ) serta variabel dependen (Siklus Menstruasi) dikumpulkan dalam waktu yang bersamaan ${ }^{9}$.Populasi merupakan keseluruhan unit dalam pengukuran yang ada dilakukan. Populasi dalam penelitian ini adalah seluruh mahasiswi tingkat I, II, dan III Akper Al ma'arif Baturaja tahun 2016 berjumlah 8 orang. Sampel merupakan bagian dari populasi yang karateristiknya akan diukur. Sampel yang diteliti menggunakan teknik total sampling adalah diamana jumlah sampel sama dengan jumlah populasi.

\section{HASIL DAN PEMBAHASAN}

Analisa yang dilakukan untk melihat hubungan antara variabel independen dan variabel dependen (siklus menstruasi), menggunakan uji statistik chi-square dan sistem komputerisasi dengan batas kemaknaan $p$ value $\leq 0,05$ dan $\boldsymbol{p}$ value > 0,05 maka kedua variabel tersebut dikatakan tidak ada hubungan bermakna

Tabel 1.

Hubungan Tingkat Stress Terhadap Siklus Menstruasi di Asrama Putri Akper Al-Ma'arif Al-Insan wilayah kerja UPTD Puskesmas Sukaraya Baturaja Tahun 2016.

\begin{tabular}{|c|c|c|c|c|c|c|c|}
\hline \multirow{4}{*}{$\begin{array}{l}\text { Tingkat } \\
\text { Stress }\end{array}$} & \multicolumn{4}{|c|}{ Siklus Menstruasi } & \multirow{2}{*}{\multicolumn{2}{|c|}{ Jumlah }} & \multirow{4}{*}{$\begin{array}{l}\text { Tingkat } \\
\text { Kemaknaan }\end{array}$} \\
\hline & \multirow{2}{*}{\multicolumn{2}{|c|}{$\begin{array}{l}\text { Tidak } \\
\text { teratur }\end{array}$}} & \multirow{2}{*}{\multicolumn{2}{|c|}{ Teratur }} & & & \\
\hline & & & & & \multirow[t]{2}{*}{$\mathbf{N}$} & \multirow[t]{2}{*}{$\%$} & \\
\hline & f & $\%$ & f & $\%$ & & & \\
\hline Stress & 37 & $72,5 \%$ & 14 & $27,5 \%$ & 51 & $100 \%$ & 0.05 \\
\hline Tidak & 12 & $38,7 \%$ & 19 & $61,3 \%$ & 31 & $100 \%$ & \\
\hline Jumlah & 49 & $59,8 \%$ & 33 & $40,2 \%$ & 82 & $100 \%$ & \\
\hline
\end{tabular}

Dari hasil penelitian didapatkan bahwa dari 82 responden. Yang mengalami menstruasi tidak teratur sebanyak 49 responden $(59,8 \%)$. Dengan stress sebanyak 37 responden $(72,5 \%)$ dan tidak stress sebanyak 12 responden ( 38,7\%). Yang mengalami siklus menstruasi teratur sebanyak 33 responden (40,2\%) dengan stress sebanyak 14 responden $(27,5 \%)$ dan yang tidak stress sebanyak 19 responden
(61,3\%). Jadi, dari uni statistik chi-square diperoleh $p$ value $0,05(<0,05)$. Hal ini menunjukkan bahwa ada hubungan tingkat stress terhadap siklus menstruasi di Asrama Putri Akper Al-Ma,arif wilayah kerja UPTD Puskesmas Sukaraya Baturaja Tahun 2016.

Hubungan tingkat stress dengan siklus menstruasi. Proposi yang mengalami 
stress lebih banyak pada mahasiswa dengan mahasiswa yang mengalami siklus menstruasi teratur yaitu 37 orang $(72,5 \%)$ dibandingkan dengan yang tidak stress dan mengalami siklus menstruasi teratur sebanyak 12 orang $(38,7 \%)$. Dari hasil uji statistik chi-square diperoleh $\mathrm{p}$ value $0,05>0,05$ hal ini menunjukkan bahwa ada hubungan bermakna antara tingkat stress dengan siklus menstruasi di Akper AlMa'arif Baturaja tahun 2016

Menurut peneliti menyatakan bahwa ada hubungan tingkat stress terhadap siklus menstruasi, dilihat dari faktor penyebab dari gangguan wanita yang mengalami gangguan menstruasi yaitu stress, hormonal, gangguan endokrin. Jadi sangat berpengaruh sekali stress terhadap kesehatan reproduksi wanita terutama pada siklus menstruasi.

Hasil penelitian ini sesuai dengan penelitian yang dilakukan oleh Mulastin, 2011 yang menyatakan bahwa dimana tidak setiap wanita mempunyai siklus menstruasi yang teratur ${ }^{10}$.

Siklus menstruasi yang tidak teratur ini dipengaruhi oleh beberapa faktor. Diantaranya adalah perubahan kadar hormone akibat stress dalam keadaan emosi yang kurang stabil. Dan penelitian ini sesuai dengan teori yang dikemukakan oleh Desti (2012) yang menyatakan bahwa stress yang berlebihan yang biasanya dikarenakan oleh pekerjaan dan masalah sehari-hari merupakan salah satu hal yang membuat siklus haid terganggu. Datangnya haid tidak akan seimbang, kadang sedikit ataupun banyak ${ }^{2}$.

Penelitian ini juga sesuai dengan teori Desti (2012) yang mengemukakan bahwa seiring dengan perkembangan medis yang tepat, penyebab terlambatnya haid tidak selamanya memicu pada penyakit yang berbahaya. Banyak penyebab yang terjadi pada wanita karena kegiatan sehari-hari. Memang perlu diwaspadai, namun sebagian lainya tidak, seperti : berat badan turun secara ekstrim, para kaum hawa yang sering melakukan diet atau program penurunan berat badan secara banyak biasanya akan mengalami gangguan pada datang bulan. Datangnya haid tidak dapat diprediksi dengan baik dan datangnya tidak teratur. Anoreksi dan bulimia, para penderita penyakit ini biasanya akan mengalami haid yang tidak teratur dan yang datang dengan jumlah yang tidak banyak. Terlalu leah, dengan kegiatan dan aktivitas yang banyak, pastinya akan mengalami haid yang datang terlambat. Jika haid sudah datang biasanya akan disertai dengan rasa sakit yang sangat. Stress, stress yang berlebihan yang biasanya dikarenakan oleh pekerjaan dan masalah sehari-hari merupakan salah satu hal yang membuat siklus haid terganggu. Dtangnya haid tidak akan seimbang, kadang sedikit atau bahkan banyak. Sakit, mengalami penyakit tertentu dapat mempengaruhi datangnya haid, ditambah dengan konsumsi obat-obatan selama sakit.

Perjalan jauh, jika banyak kegiatan diluar kota atau sering berpegian dengan perjalanan jauh, maka tubuh anda akan pasti akan mengalami rasa lelah yang berpengaruh pada pembuahan dirahim, oleh karena itu pelepasan telur akan terlambat. Mengkonsumsi narkoba, para wanita yang banyak memakai obat-obatan terlarang dipastikan akan mempengaruhi masalah terhadap siklus haid. Biasanya datngnya akan tidak teratur dan sering sangat terlambat. Sedang menyusui, hal ini normal bagi wanita yang menyusui. Adanya keterlambatan dengan jumlah haid yang sedikit.

Hal ini menunjukkan bahwa tingkat stress merupakan salah satu faktor pemicu yang menyebabkan adanya gangguan siklus menstruasi tiap individu masing-masing. Dikarenakan stress akan mempengaruhi sistem kerja dari hipotalamus. 
Hipotalamus senidiri merupakan organ yang bertanggung jawab pada kontrol kelenjar pituitary, yang memegang kontrol kelenjar tiroid, adrenalin dan ovarium. Ketiga kelenjar ini akan bekerja sama-sama dalam mengatur stabilitas dan keseimbangan hormon di tubuh manusia.

\section{DAFTAR PUSTAKA}

1. Pardede N. Masa remaja. Dalam: Narendra MB, Sularyo TS, Soetjiningsih, Suyitno H, Ranuh ING, Wiradisuria $\mathrm{S}$, penyunting. Tumbuh kembang anak dan remaja. Jakarta: Sagung Seto; 2002. h. 138-70.

2. Desty NI.2010. Hubungan antara stres dengan pola menstruasi pada Mahasiswa DIV Kebidanan jalur regular. Universitas Sebelas Maret Surakarta.

https://www.google.com/url?sa=t\&rct $=\mathrm{j} \& \mathrm{q}=\&$ esrc $=\mathrm{s} \&$ source $=$ web $\& \mathrm{~cd}=\& \mathrm{c}$ $\mathrm{ad}=\mathrm{rja} \& u a c t=8 \& \mathrm{ved}=2 \mathrm{ahUKEwj}$ Dne jW_ozqAhUxg-

YKHQ9iDTcQFjAGegQIBxAB\&url $=$ https\%3A\%2F\%2Fdigilib.uns.ac.id \%2Fdokumen $\% 2$ Fdownload\%2F165 24\%2FMzE2OTQ\%3D\%2FHubunga n-antara-stres-dengan-polamenstruasi-pada-mahasiswa-d-IVkebidanan-jalur-reguler-UniversitasSMaret-Surakartaabstrak.pdf\&usg=AOvVaw0YH6HgI 7TuetKDqkb8JIS6

3. Wijaya AM. 2009. Pelayanan Kesehatan Peduli Remaja. http;//www. infodokterku. Com

4. Sukhraini, I.N. (2011). Hubungan Stres Dengan Siklus Menstruasi Yang Tidak Teratur Pada Mahasiswi Fakultas kedokteran USU Angkatan 2007.

5. Cakir, M., Mungan, I., Karakas, T., Giriskes, I.,\& Noczyska, A. (2007).
Menstrual Pattern and Common Menstrual Disorder among University Students in Turkey.Pediatrics International, 49(6).

6. Bieniasz, J., Zak, T., A-Laskowska, Z.,\& Noczyska, A. (2007). Menstrual Pattern and Common Menstrual disorder in Adolescent Girls_ a retrospective Study. Endokrynol Diabetol Chor Przemiany Materi Wieku Rozw, 12(3), 205-10.

7. Williams S R. 2006. Menstrual cycle characteristics and predictability of ovulation of bhut in a women in Sikkim, ndia.j phsyol Antropol 2006: 25:85-9

8. Depkes RI. (2007). Profil Kesehatan 2007. Departemen Kesehtan RI.

9. Notoatmodjo, S. 2005. Pendidikan dan perilaku kesehatan. Edisi revisi. Jakarta: Rineka Cipta. 2005. h. 28-34

10. Mulastin. (2011). Hubungan Status Gizi dengan Kejadian Dismenorea Remaja Putri di SMA Islam AlHikmah Jepara. Diakses pada tanggal 12 Juli 2017 dari 